\title{
Chemical and Histological Differences of Maize (Zea mays L.) Responsive to Harpophora maydis Infection
}

\author{
Nasr Ahmed Ghazy ${ }^{1}$, Shokrey El-Gremi ${ }^{2}$, El-Sayed Belal ${ }^{2}$ \\ ${ }^{1}$ Maize And Sugar Crops Dis. Dept., Plant Pathol. Res. Inst., Agric. Res. Center, Giza, Egypt. \\ ${ }^{2}$ Agric. Botany Dept., Fac. Agric., Kafrelsheikh Univ. Egypt.
}

\begin{abstract}
Harpophora maydis (formerly Cephalosporium maydis) is considered to be one of the most destructive pathogens causing late wilt disease of maize in Egypt. Therefore, the current investigation aimed to enlighten the relationship between the host (Zea mays) and the pathogenic agent (Harpophora maydis), included the chemical and histological differences between susceptible and resistant cultivars. Pathogen isolation was carried out through five Governorates in Egypt (Kafr El-Sheikh, El-Behera, El-Dakahlya, El-Menia and Sohage). Five obtained isolates differed in their virulence based on the pathogenicity test with five cultivars (SC.10, SC.123, TWC.310, Giza-2 and Balady). The maize cultivar (SC.10) was resistant to all the tested isolates. While the cultivar Balady showed the highest susceptibility. Isolate H. maydis No.5 isolated from Sohage Governorate was the most virulent isolate (disease incidence 25.75\%), while isolate No.4 was the least virulent isolated from Menia Governorate (1.6\%). Moreover, under artificial infection stress, linear increment of phenolic contents and total soluble sugars was observed with the resistant cultivar compared to susceptible one at 30, 60 and 90 days from planting. The obtained results showed highly significant (33.64 mg $10 \mathrm{~g}^{-1}$ fresh weight) with susceptible cultivars relative to resistant one $\left(23.18 \mathrm{mg} 10 \mathrm{~g}^{-1}\right)$, for total soluble sugars contents.Also, results of phenolic contents gave a similar trend. For thickness of sheath bundle, thickness of the sheath-layer obviously increased with aging of plants, and thickness in both of resistant and susceptible cultivars was affected after infection process. Uninfected resistant plants showed increase in thickness of the scleronchymateous sheath-layer surrounding the vascular bundles compared with that of the susceptible uninfected plants. Consequently, phenolic contents may play an essential role in resistance process against late wilt disease as well as sugar contents with susceptibility process.
\end{abstract}

Keywords : Harpophoramaydis, Histopathology, Phenols, Sugars, Zea mays.

\section{Introduction}

Maize (Zea Mays L.) is known to be an important cereal crop in Egypt since it rated as the third crop after wheat and rice crops. Late wilt is a vascular disease of maize that caused by the soilborne fungus, Harpophoramaydis (Gams) with synonyms: CephalosporiummaydisSamra, Sabet, \& Hingorani(Samra et al. 1963). Serious economic losses from late wilt have been reported. In Egypt yield losses of up to $40 \%$ have been reported (Jain et al. 1974; El-Shafey and Claflin 1999), while reached up to $100 \%$ in India (Satyanarayana 1995). Maize plants infected with pathogen show fast wilt symptoms before tasseling and continue until maturity. The effective way for controlling disease is selection of resistant cultivars (Degani and Cernica, 2014). Variations in virulence of the
Egyptian isolates of C. maydis were recorded by various researchers, (Fayzalla et al. 1994; ElAssiuty et al. 1998; Awad 2002 and Saleh 2002). The first appearance of the late wilt symptoms was 85-90 days after sowing in the artificially infected plants under nursery field (Awad 2002 and Saleh 2002).

In the presence of the causal agent, maize cultivars differ in their response to the late-wilt disease (Awad 2002 and Saleh 2002). Resistant maize plants contained higher phenolic compounds than those of the susceptible plants (Sadik 1973 and Rushdi et al. 1975). In vitro, phenolic acids (cinnamic and ferulic acids), found in the resistant maize cultivars, were able to suppress the growth of C. maydis (El-Fangary 1975). Obtained results by Kostandi (1979) showed that, phenolic 
compounds concentrates of some maize lines stem tissues of the third internodes from 30 to 90 days from sowing were significantly varied. Also, the maize lines of highly resistant category was the highest in phenolic content, while the maize lines of highly susceptible category were the least in total phenolics. The concentrations of total phenolic compounds were higher at tasseling stage than at seedling stage of the tested healthy and diseased maize plants. Thereafter, the phenolic concentrations sharply decreased at the maturity stage in both healthy and diseased plants. The highest virulent isolates were the most responsive for increasing the concentration of phenolic compounds in their host (Abou El-Seood 1982). Susceptible maize inbred lines and hybrids were characterized to exhibit lower level of total and free phenols than in the resistant inbred lines and hybrids (Nazim et al. 1990). The phenolic content in all cultivars of maize increased after infection. This increase was more pronounced in resistant cultivars as compared to susceptible cultivars. The highest increase (32.14\%) in accumulation of phenolics was noticed in diseased leaves of genotype BVM-4 infected with the Rhizoctonia solani isolate. Further analysis of obtained data revealed that the disease severity was negatively correlated with the accumulation of phenol (Akhtaret al. 2011). When maize plants were examined 6 and 13 weeks after infected, no relation was found between sugar content and intensity of stalk-rot disease (Czaplinskaet al. 1979).

In healthy maize plants, stems of the highly susceptible variety (Giza Balady) contained less sugar contents than the highly resistant (DH 203) and the moderately resistant (Giza-2). The sugar contents of stalks generally decreased with the increase of plant age. However, infection with $C$. acremonium, C. maydis and Fusarium moniliform (the causal agents of the stalk-rot disease) resulted in increasing in the sugar contents in both varieties (Abd El-Ghani1987). It is known that response to disease may primarily depend on the structure of the host plant (Johan and Dickson 1945). Mycelial growth was clearly found in the bundles of roots and stems at 110 days of maize plants infected with $C$. maydis and $C$. acremonium. In the resistant varieties, the fungus was found in the infected roots and rarely found in the vessels of lower internodes of the stem (Fadle 1968). Also, root of resistant cultivar had been more layers of exodermal collenchymateous cells, smaller compact endodermal cells with thick walls, layer scleronchymateouscell of pericycle, more layers of larger scleronchymateous cells with thick walls surrounding the xylem vessels, and smaller pith than roots of susceptible cultivar (Sadik 1973; Rushdi et al. 1975). On the other study, roots of Giza-4 and Giza-102 inbred lines susceptible to $C$. maydis exhibited less collenchymateous cells in their exoderms than those of resistant inbred lines Giza-221 and Giza-249. They also found that vascular bundles of resistant inbred revealed higher number of xylem vessels than those of susceptible one, and pith area was much greater in resistant inbred lines than in susceptible one (Saeed et al. 1990). Abd El-Rahim et al. (1998) concluded that occlusion may be the most important factor causing the symptoms of disease. The present investigation aimed to enlighten the relationship between the host and the pathogenic agent of the maize late wilt disease. This work included the chemical and histological difference between susceptible and resistant cultivars.

\section{Materials and Methods}

\section{Isolation and identification of the pathogen}

Sampling of diseased plants

Samples of maize plants showing typical symptoms of the late wilt disease were collected from five Governorates in Egypt (Kafr El-Sheikh, El-Behera, El-Dakahlya, El-Menia and Sohage). The samples were randomly collected from different fields and used to isolate the pathogenic agent.

\section{Isolation of the causal pathogen}

The isolation was performed using methods described by Awad (2002). The lower third to fifth internodes of diseased plants were thoroughly washed with running tap water and cut into small pieces of $1 \mathrm{~cm}$ in length. Pieces were surface sterilized by immersing in $0.5 \%$ sodium hypochlorite solution for $3 \mathrm{~min}$ then, washed several times in sterilized water and blotted between two sterilized filter papers. Under aseptic conditions, internal tissues were transferred onto Petri dishes containing Potato Dextrose Agar medium amended with $2 \mathrm{~g}$ yeast extract $\mathrm{L}^{-1}$ (PDAY) as recommended by (Abd ElGhani 1987; Yassin 2000). Dishes were incubated at $28{ }^{\circ} \mathrm{C}$ for 3-7 days and examined daily for observing the fungal growth. The growing isolates were examined microscopically and purified using the hyphal tip technique described by (Dhingra and Sinclair 1995). Pure cultures of the obtained isolates were maintained on PDAY 
slants and kept at $4^{\circ} \mathrm{C}$ for further experiments. Each isolate had its code number (1-5)matched with the order of five Governorates Kafr ElSheikh, El-Behera, El-Dakahlya, El-Menia and Sohage, respectively.

Identification of the pathogen

Cultural and microscopic characters: Identification of the obtained isolates was carried out based on the morphological characteristics of growth and microscopic examination features.

Pathogenicity tests: This experiment was carried out under greenhouse conditions at Sakha Agriculture Research Station, Agriculture Research Center, Egypt. According to El-Shafey et al. (1988), the soil infected technique was used. Grains of sorghum were thoroughly washed, air dried and then distributed into the bottles (500 $\mathrm{ml}$ )at the rate of $50 \mathrm{~g}$ per each. Bottles were autoclaved at $1.5 \mathrm{~kg} \mathrm{~cm}^{-2}$ for $45 \mathrm{~min}$. Bottles were inoculated with discs of 10 days of cultures and incubated at $28{ }^{\circ} \mathrm{C}$. After sufficient growth had been obtained, contents of the bottles of each isolate were thoroughly mixed. Pots of $30 \mathrm{~cm}$ diameter and $35 \mathrm{~cm}$ depth, (previously sterilized by soaking in 7\% formaldehyde solution for 10 min and left for 10 days to be aerated) were filled with autoclaved field soil at $1.5 \mathrm{~kg} \mathrm{~cm}^{-2}$ for 45 min. Soil in pots was mixed thoroughly with the prepared inoculum at the rate of $10 \mathrm{~g} \mathrm{~kg}^{-1}$ soil. Infected pots were kept moistened 7 days before sowing. Grains of maize cultivars owing different susceptibility degree, Single Crosse 10 (SC.10), Single Crosse 123 (SC. 123), Three Way Cross 310 (TWC. 310), Giza-2 and Balady) were sown at rate of 5 grain spot ${ }^{-1}$ in 4 replicates for each variety. Uninfected sown pots were used as check treatment controls. Ammonium nitrate fertilizer was added at the rate of $0.4 \mathrm{~g} \mathrm{pot}^{-1}$ at 30,45 and 60 days after sowing, and plants were irrigated when necessary as recommended by (Sadik1973).

Disease readings were recorded after 90 days of sowing (35 days from silking) and expressed as percentages of diseased plants. The disease incidence percentages were recorded according to Awad (2002), as following:

$$
\text { Disease incidence }=\frac{\text { No. of diseased plants }}{\text { Total No. of plants }} \times 100
$$

Based on the scale mentioned by Saleh (2002), the tested cultivars were classified to 4 categories as following:-
1. Highly Tolerant (HT), where the recorded disease incidence percentages were $<$ or $=$ $5 \%$.

2. Tolerant $(\mathrm{T})$, where the recorded disease incidence percentages were $>5$ to $10 \%$.

3. Moderately Tolerant (MT), where the recorded disease incidence percentages were $>10$ to $15 \%$.

4. Susceptible (S), where the recorded disease incidence percentages were more than $15 \%$.

Fungal isolates graded as the highest and the least virulent and the plant cultivars graded as the resistant and susceptible were all selected for next experiments.

\section{Determination of chemical compounds \\ Plant extraction}

Among the five maize cultivars, two cultivar (SC.10 and Balady) were selected from the pathogenicity experiment as resistance and susceptible cultivars, respectively. Single cross 10 (SC.10) maize cultivars were sown in pots containing soil infected with the most virulent isolate under greenhouse conditions. Uninfected pots were also sowing as control. Ten grams of fresh weight for each plant samples were collected periodically at 30,60 and 90 days after sowing. Samples of different plant parts i.e.leaves, stems, roots and tassels were randomly taken for each plant to be extracted according to Snell and Snell (1953). Samples were cut into small pieces and immediately were dipped into boiling $95 \%$ ethanol for $10 \mathrm{~min}$ to stop further enzymatic activities. The extraction was then resumed in Soxhlet apparatus using $75 \%$ ethanol for $8 \mathrm{~h}$. The combined ethanolic extracts were filtered and evaporated to near dryness on a warm water bath $\left(60^{\circ} \mathrm{C}\right)$. The extract was redissolved in $5 \mathrm{ml}$ of $50 \%$ isopropyl alchohol, and then used for chemical analysis.

\section{Determination of total phenols}

According to Snell and Snell (1953), total phenols were determined by adding 10 drops of conc. $\mathrm{HCl}$ to $1 \mathrm{ml}$ of sample. The mixture was heated rapidly till boiling over free flame, and then placed in a boiling water-bath for 10 min. After cooling, $10 \mathrm{ml}$ of the reagent FolinDenis(Folinand Denis 1912) and $25 \mathrm{ml}$. of 20\% sodium carbonate solution were added. The mixture was diluted to $100 \mathrm{ml}$ using distilled water. After $20 \mathrm{~min}$, the developed colour was 
measured at $520 \mathrm{~nm}$ against the reagent blank on the spectrophotometer (MiltoroySpectronic1210). Phenolic compounds were expressed as $\mathrm{mg}$ catechol $10 \mathrm{~g}^{-1}$ fresh weigh based on the standard curve for catechol.

Determination of total soluble sugars

In the same previously extracted samples, the total soluble sugars were determined colorimetrically using the picric acid methods described by Thomas and Dutcher (1924). Two solutions were used for determination:

\section{Picrate picric solution}

Thirty six grams of picric acid were added to $500 \mathrm{ml}$ of $1.0 \%$ sodium hydroxide in one liter flask, then $400 \mathrm{ml}$ of hot water were added and the mixture was occasionally shaken until the picric acid was dissolved, then mixture was cooled and diluted to one liter.

\section{Sodium carbonate solution}

Twenty grams of sodium carbonate were dissolved in $100 \mathrm{ml}$ of distilled water.For determination of the total soluble sugars $1 \mathrm{ml}$ of each sample extracted was transferred into the bottle $(100 \mathrm{ml})$ containing $5 \mathrm{ml}$ of distilled water and $4 \mathrm{ml}$ picrate picric solution. The mixture was boiled for $10 \mathrm{~min}$ in a water-bath. After cooling $0.4 \mathrm{ml}$ sodium carbonate solution was added and the mixture was boiled again for $10 \mathrm{~min}$. When the tube became cold, the mixture was completed to $50 \mathrm{ml}$ with distilled water. The optical density of the developed colour was measured using spectrophotometer (MiltoroySpectronic 1210), against the reagent blank at $540 \mathrm{~nm}$. Total soluble sugar content was expressed as mg glucose 10 $\mathrm{g}^{-1}$ fresh weight of samples. A standard curve was obtained using determined concentrates of glucose.

\section{Histology of maize plants}

According to methods used by Abd El-Ghani (1987), stem segments taken from the second lower internodes were fixed in a mixture (10: 5 : 50: $35 \mathrm{ml}$ ) of formalin, acetic acid, ethyl alcohol $70 \%$ and water, respectively, for $36 \mathrm{~h}$. The fixed specimens were transferred to $70 \%$ ethanol until they were used. Dehydration was performed in increasing concentrations of ethanol and $\mathrm{N}$-butanol series, then embeded in a paraffin wax $\left(58^{\circ} \mathrm{C}\right.$ melting point). Cross sections were cut by a rotary microtome, (approximately $15 \mu \mathrm{m}$ thickness) and fixed on microscopic slides with Haupt's adhesive $(1 \mathrm{~g}$ gelatin $+100 \mathrm{ml}$ water $+2 \mathrm{~g}$ phenol $+15 \mathrm{ml}$ glycerol), as mentioned by (Sass 1961). Slides were left to complete dryness for $24 \mathrm{~h}$ in oven at $40^{\circ} \mathrm{C}$. Sections were stained with $1 \%$ safranine and $1 \%$ light green dyes, cleared in xylene, mounted in Canada balsam and examined microscopically.

\section{Results}

Isolation and identification of the pathogen

Samples of the diseased plants collected from different chosen locations includes 5 Governorates were used to collect different geographic isolates of the pathogen. All obtained isolates were tested for their cultural, microscopic and pathogenic characters. The main common cultural and microscopic characters coincide with that of the fungus $H$. maydis. Regarding to the virulence, the pathogenicity tests revealed that the obtained isolates differed in their virulence. Their ability to cause the late wilt disease and the degree of the disease varied depending on the isolate and the tested maize cultivar as shown in Table 1 and Fig. 1. However, all the tested isolates proved their pathogenic character of the fungus H. maydis since they infected and diseased one or more of the tested cultivars causing typical symptoms of the late wilt disease. Results in Table 1, indicate that the most virulent isolate of H.maydiswas the isolate No.5 which was isolated from Sohage Governorate. It caused $25.75 \%$ as mean of disease incidence on the tested maize cultivars. Furthermore, the isolate No.5 attacked and diseased 4 of the tested cultivars, i.e. SC.123, TWC.310, Giza-2 and Balady where the recorded disease incidence percentages were $10 \%, 7.14 \%, 42.38 \%$ and $69.23 \%$, respectively. On the other hand, the isolate No.4 which was isolated from Menia governorate had the least virulence where it could attack and diseased only the maize cultivar TWC.310 and failed to cause the late wilt disease on the remained maize cultivars SC.10, SC.123, Giza-2 and Balady.

Among the tested cultivars, the variation in response towards infection by the pathogenic agent of the late wilt disease again was proved. The maize cultivar Balady showed the most susceptible to the late wilt disease. The highest recorded disease incidence percentage (69.23\%) was obtained on the Balady cultivar. In addition, this cultivar was infected and diseased by the three $H$. maydis isolates, (1, 3 and 5) where the achieved disease incidence percentages reached 
$53.33 \%, 7.69 \%$ and $69.23 \%$, respectively. In contrast, the maize cultivar SC.10 showed high resistance to the infection by all tested $H$. maydis isolates where no symptoms of the late wilt disease were recorded in the presence of any isolate of the pathogen. According to the previous results the highly virulent isolate No.5, the highly resistant (HR) cultivar SC.10 and the susceptible cultivar Balady were chosen for further experimental tests.

Differences between the susceptible and resistant cultivars

To determine either of factors responsible in the response of maize cultivars towards the

TABLE 1. Pathogenicity test of the obtained isolates of H.maydis on different cultivars of maize under greenhouse conditions.

\begin{tabular}{ccccccc}
\hline \multirow{2}{*}{ Isolate } & \multicolumn{5}{c}{ \% disease incidence } & \multirow{2}{*}{ Control } \\
\cline { 2 - 5 } Maize cultivar & No.1 & No.2 & No.3 & No.4 & No.5 & \\
\hline SC.10 & 0.0 & 0.0 & 0.0 & 0.0 & 0.0 & 0.0 \\
SC. 123 & 42.85 & 8.33 & 0.0 & 0.0 & 10.00 & 0.0 \\
TWC. 310 & 10.00 & 0.0 & 0.00 & 8.0 & 7.14 & 0.0 \\
Giza-2 & 11.11 & 13.33 & 9.09 & 0.0 & 42.38 & 0.0 \\
Balady & 53.33 & 0.0 & 7.69 & 0.0 & 69.23 & 0.0 \\
\hline
\end{tabular}

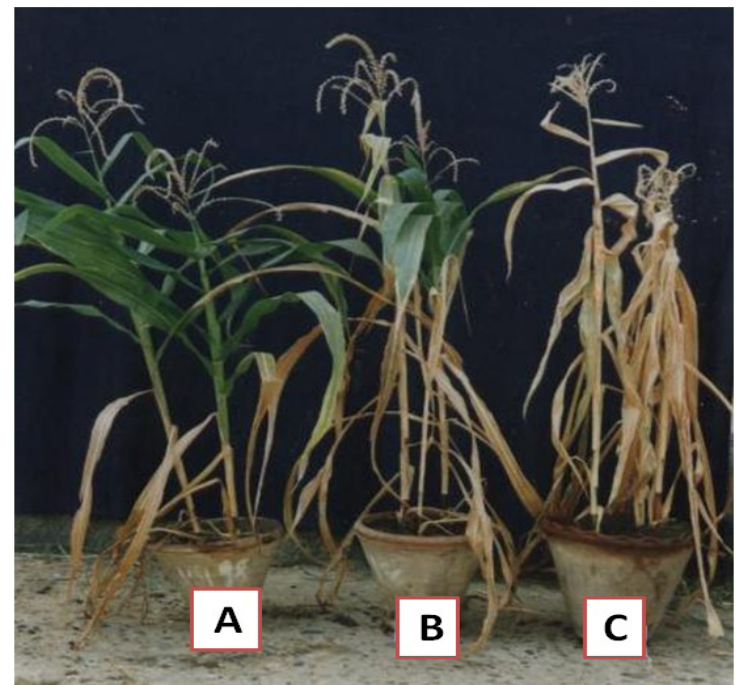

I

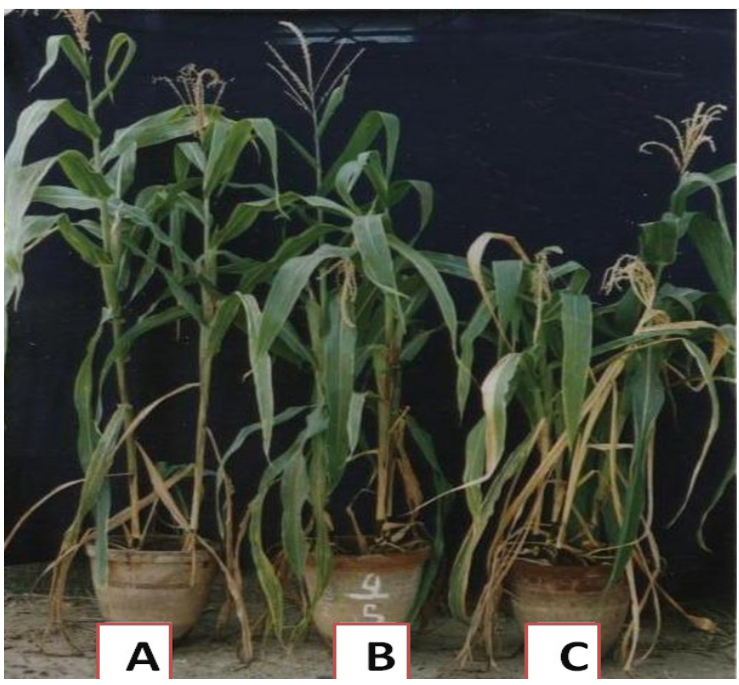

II

Fig. 1: Reaction between different $\boldsymbol{H}$. maydis isolates and maize cultivars

I- The most virulent isolate (No.5)

$A=$ the resistance cultivar (SC.10)

$\mathrm{C}=$ the most susceptible cultivar (Balady)

incidence of the late wilt disease, differences between the highly resistant (HR) cultivar SC.10 and the susceptible cultivar Balady were chemically and anatomically distinguished.

Differences in the total phenols

Determination of the total phenolic contents in uninfected plants revealed higher contents in the resistant cultivar SC.10 than that in the susceptible

\section{II=the least virulent isolate (No.4)}

$\mathrm{B}=$ the moderate cultivar (SC.123)

Balady cultivar (Table 2). Data presented in Table 2, indicate that the estimated average of total phenolic compounds reached $38.72 \mathrm{mg} 10$ $\mathrm{g}^{-1}$ fresh weight of the resistant plants compared

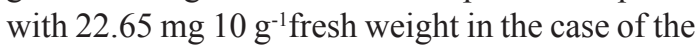
susceptible plants. It is worthy to be noticed that a linear increase in the phenolic contents with aging was observed in the healthy plants of the resistant 
cultivar but not obviously detected in case of the susceptible one. However, in the presence of infection, the response of the susceptible plants was intensive where the phenolic contents were more induced. The recorded phenolic contents raised from $23.57,17.23$ and $27.16 \mathrm{mg} 10 \mathrm{~g}^{-1}$ fresh weight of the uninfected plants up to $26.5,23.36$ and $30.11 \mathrm{mg} 10 \mathrm{~g}^{-1}$ fresh weight of the infected plants at the three sampling times, respectively. As shown in Table 2, this phenomenon was not detected in case of the resistant plants.

Differences in the total soluble sugars

Regarding to the total soluble sugars contents, data presented in Table 3, indicated that in healthy maize plants, opposite trend to that of the total phenolic contents was detected especially at 30 and 60 days. At these sampling times, the uninfected susceptible plants showed higher soluble sugars contents (10.8 and $18.4 \mathrm{mg} 10 \mathrm{~g}^{-1}$ fresh weight, respectively) compared to the resistant plants ( 8.4

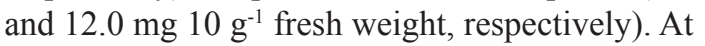
the third sampling time (90 days from planting), the soluble sugars contents lowered down in both the susceptible and the resistant plants (8.93 and $9.2 \mathrm{mg} 10 \mathrm{~g}^{-1}$ fresh weight, respectively). In the presence of infection, increases in soluble sugars contents were recorded as in the susceptible. However the response of the susceptible plants was higher. The mean of soluble sugars contents raised from $12.71 \mathrm{mg} 10 \mathrm{~g}^{-1}$ fresh weight of the healthy susceptible plants to $33.64 \mathrm{mg} 10 \mathrm{~g}^{-1}$ fresh weight of the diseased plants. In comparison, that mean was recorded as 9.87 and $23.18 \mathrm{mg} 10 \mathrm{~g} \mathrm{~g}^{-1}$ fresh weight of healthy and infected resistant plants, respectively.

\section{Histological differences}

To determine either of specific histological differences between the susceptible and the resistant maize plants or their response to inoculation by $H$. maydis, cross sections were made in the $2^{\text {nd }}$ lower internodes sampled at 30 , 60 and 90 days from planting. Figure 2, illustrated all the obtained experimental results. Cross section of the uninfected resistant plants at the three times pictures labeled by the letters (A, C $\& \mathrm{E})$ in Fig. 3, showed increase in thickness of the scleronchymateous sheath-layer surrounding the vascular bundles compared with that of the susceptible uninoculated plants at the same respective sampling times pictures labeled by the letter (A, C \&E) in Fig. 2. Generally, thickness of the sheath-layer obviously increased with aging of plants. In the presence of inoculation, layers of the vascular-sheath increased in the resistant plants pictures labeled by the letters (B, D \& F) in Fig. 3, compared with that in the susceptible ones at the same respective sampling times pictures labeled by the letters (B, D \& F) in Fig. 2. Aging led to more increase in the scleronchymatous sheath layer. It is worthy to be noticed the presence of H. maydis aggregates in xylem vessels of the susceptible maize cultivar Balady only at 90 days from planting (Fig. 2F). In the same time, xylem vessels of the resistant maize cultivar SC.10 appeared free from H. maydis (Fig. 3F).

\section{Discussion}

The late-wilt caused by the fungus $H$. maydis, is an important disease of maize, especially in Egypt. Firstly, it was important to test the

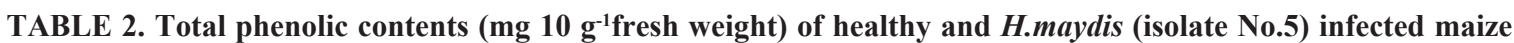
plants of susceptible (Balady) and resistant (SC.10) cultivars at different stages of growth.

\begin{tabular}{cccccc}
\hline Maize & Treatments & \multicolumn{2}{c}{ Total phenols $\mathbf{( m g ~ 1 0 ~ \mathbf { ~ g } ^ { - 1 } \text { fresh weight) }}$} & \multirow{2}{*}{$\begin{array}{c}\text { Mean of } \\
\text { Total phenols }\end{array}$} \\
\cline { 3 - 4 } Cultivar & & $\mathbf{3 0}$ days & $\mathbf{6 0}$ days & $\mathbf{9 0}$ days & 26.66 \\
Balady & Infected & 26.50 & 23.36 & 30.11 & 22.65 \\
& Uninfected & 23.57 & 17.23 & 27.16 & 32.14 \\
\multirow{2}{*}{ SC.10 } & Infected & 28.47 & 35.10 & 32.85 & 38.72 \\
& Uninfected & 30.85 & 37.66 & 47.65 & \\
\hline
\end{tabular}

TABLE 3. Total soluble sugars contents $\mathrm{mg} 10 \mathrm{~g}^{-1}$ fresh weigh of healthy and H.maydis (isolate No.5) infected maize plants of susceptible (Balady) and resistant (SC.10) cultivars at different stages of growth.

\begin{tabular}{|c|c|c|c|c|c|}
\hline \multirow[t]{2}{*}{$\begin{array}{c}\text { Maize } \\
\text { Cultivars }\end{array}$} & \multirow[t]{2}{*}{ Treatments } & \multicolumn{3}{|c|}{$\begin{array}{c}\text { Total soluble sugar } \\
\text { (mg } 10 \mathrm{~g}^{-1} \text { fresh weight) }\end{array}$} & \multirow[t]{2}{*}{$\begin{array}{l}\text { Mean of total } \\
\text { soluble sugar }\end{array}$} \\
\hline & & 30 days & 60 days & 90 days & \\
\hline \multirow[t]{2}{*}{ Balady } & Infected & 28.40 & 34.00 & 38.53 & 33.64 \\
\hline & Uninfected & 10.80 & 18.400 & 8.93 & 12.71 \\
\hline \multirow[t]{2}{*}{ SC.10 } & Infected & 16.93 & 21.00 & 21.60 & 23.18 \\
\hline & Uninfected & 8.40 & 12.00 & 9.20 & 9.87 \\
\hline
\end{tabular}

Env. Biodiv. Soil Security Vol.1 (2017) 

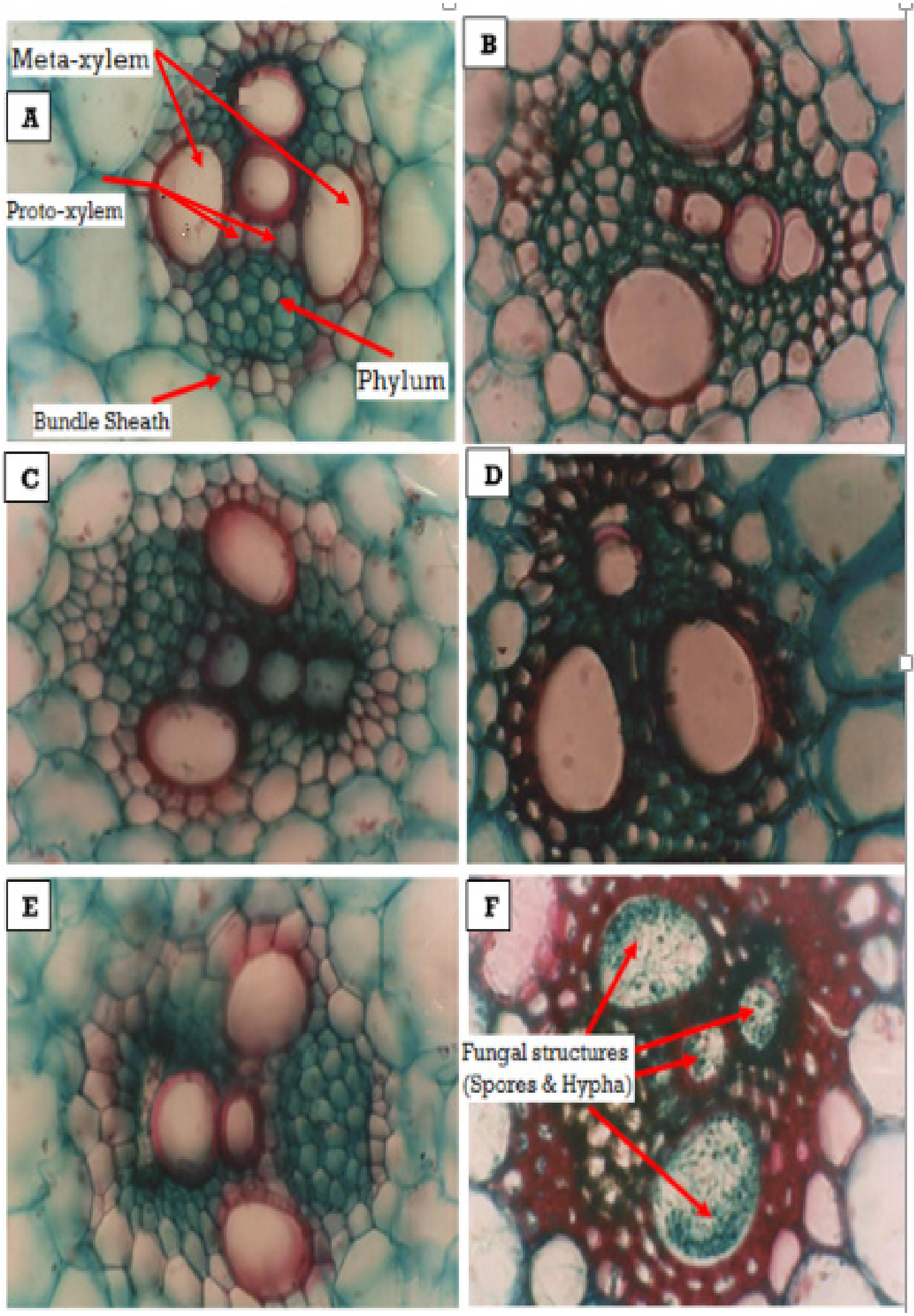

Fig. 2. Transverse section ( $X$ 400) in the 2nd stem internode of Balady maize cultivar plants at 30 days from planting (A, control \& B, infected), 60 days $(C$, control \& $D$, infected) and 90 days (E, control \& F, infected). 

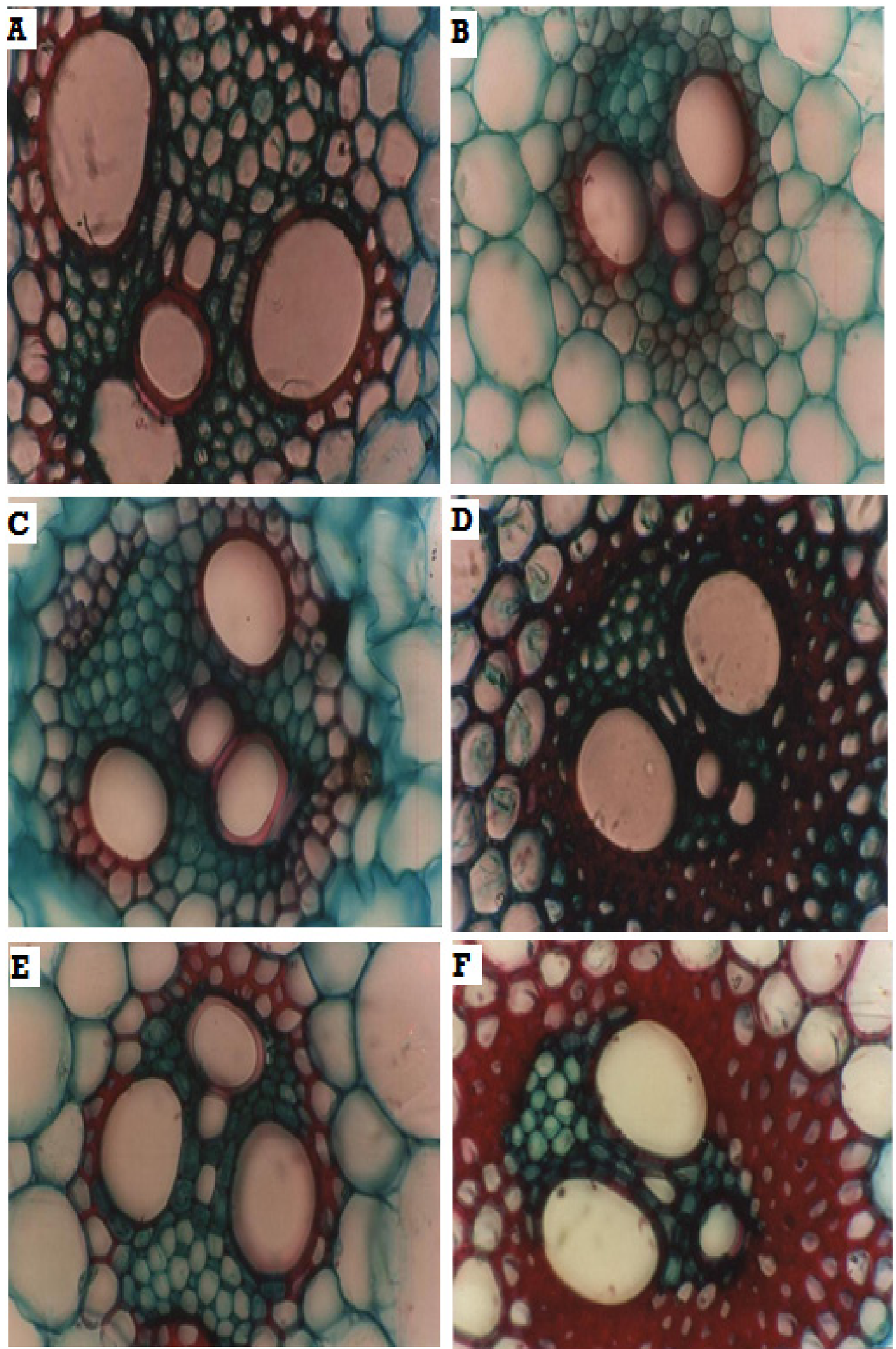

Fig. 3. Transverse section $(X 400)$ in the $2 \mathrm{nd}$ stem internode of SC.10 maize cultivar plants at 30 days from planting (A, control \& B, infected), 60 day (C, control \& $D$, infected) and 90 days (E, control \& F, infected). 
response of different maize cultivars to infection with $H$. maydis under controlled conditions with soil infestation conditions of both artificial and natural soil infestation. Depending on the obtained percentages of the disease incidence, the tested genotypes of maize could be generally classified to three main categories: tolerant, moderate and susceptible. Obtained results of previous work done by Awad (2002) and Saleh (2002) dealing with this topic, interfere in grouping could be noticed among the same tested genotypes of maize against C. maydis. Therefore, biotic and abiotic factors play a great role in this respect. However, few of the tested maize cultivars had strict reactions. In the present study as well as other reported results, maize cultivars SC.10 and Balady showed resistance and susceptibility reactions against the late wilt pathogen, respectively.

Under controlled conditions, different isolates of the late wilt pathogen were obtained from different geographic locations covering five Egyptian Governorates. Although, all the obtained isolates showed the same cultural and microscopic characteristics which were specific to the fungus H.maydis. The pathogenic reaction varied depending on the tested isolate and the infected maize cultivars. Variation of pathogenicity and virulence amongst $C$. maydis isolates were proved in other works El-Shafeyet al. (1985); Singh and Siradhana (1987); Hassaballaet al. (1987); Fayzallaet al.(1994); El-Assiutyet al. (1998); Awad (2002), and Saleh (2002). This variation is thought to be genetically and serologically based. Awad (2002) differentiated between $C$. maydis isolates that differed in their virulence using the Random Amplified Polymorphic DNA (RAPD) method for DNA analysis as well as by the serological method. The RAPD dendogram of C. maydis isolates showed that the isolate-clusters differed according to their virulence. In the serological study, the author detected one antigen associated to the virulence.

Propagules of isolate No.5 could be observed in prepared cross sections of infected plants colonizing the xylem vessels. Mechanical suppression of water uptake through such plugged vessels could be concluded. Capability of the $H$. maydis virulent isolates to plug the host plant xylem vessels was previously proved by Mansour (1962), Samra et al. (1966), Fadle (1968), Sabet et al. (1970), Zaher (1974), El-Shafey et al.(1979), Abd El-Ghani (1987) and Khalifa (2000). In the present work, the host plant, as a partner in the pathogenic relationship showed various response reactions accordingly with both its histological structure and its chemical possessions. Thickness of sheath bundles surrounding the vascular bundles was increased through the cross section of healthy resistant cultivar SC.10 compared to susceptible balady cultivar. More layers of sclerenchymateous cell surroundings the xylem vessels in resistant maize cultivars against $C$. maydis were found by Sadik (1973) in which may act as mechanical barriers protecting bundles against the pathogen invasion.

In addition to differences in the histological structure, chemical analysis of the two maize cultivars SC.10 and Balady revealed higher phenolic contents in SC.10 cultivar while higher sugar contents were recorded in Balady. Correlation between contents of phenols and sugars in maize plants and their response to the pathogenic invadors noticed by Abou El-Seood (1982), El-Shabrawy et al. (1987), Abd El-Ghani (1987), Nazim et al. (1990), El-Laithy (1996), Gouda (1996) and Shetty et al. (2001) assured this trend. Phenols as phytochemical compounds have numerous functions; one of these functions is protection of plant against pathogens (Nicholson 1992). On the other hand, sugars proliferated in the susceptible Balady cultivar may be in favour of the pathogen as a carbon source of nutrition.

\section{References}

Abd El-Ghani, Haifa, S. (1987) Studies on stalk-rot disease of corn in Egypt. Ph. D. Thesis, Fac. Agric., Ain Shams Univ., Cairo, Egypt.

Abd El-Rahim, M. F., Fahmy, G. M. and Fahmy, Zeinab, M. (1998) Alteration in transpiration and stem vascular tissues of two maize cultivars under conditions of water stress and late wilt disease. Plant Pathol., 47, 216-223.

Abou El-Seood, M. S. (1982) Studies on the physiology of certain maize stalk rotting fungi. Ph. D. Thesis, Fac. Agric., Alex. Univ., Egypt.

Akhtar, J., Jha, V. K and Lal, H. C. (2011) Post-infectional phenolic changes in maize due to Rhizoctonia solani f. sp. sasakii causing banded leaf and sheath blight. Indian Phytopathl. 64 (3), 261-264 (2011).

Awad, H. E. M. F. (2002) Studies on late wilt disease of maize. Ph. D. Thesis, Fac. Agric. Kafr El-Sheikh, Tanta Univ., Egypt.

Czaplinska, Cebrat, S. J., Kobierzynska Golab, 
Szuwalska, Z. and jasa, S. (1979) The search for methods of assessing the resistance of maize plants to basal stalk rot. 13 juletypeInstytutu Hodowliji Alkimatyzacjiroslin, No. 136, 79-90. (C.F Abd ElGhani, Haifa, S., 1987).

Degani, O and Cernica, G. (2014) diagnosis and control of Harpophora maydis, the cause of late wilt in maize. Advances in Microbiology, 4, 94-105

Dhingra, O. D. and Sinclair, J. B. (1995) Basic Plant Pathology Methods. Second Edition, CRC Press, Inc. Chapter 6, 217-266.

El-Assiuty, E. M., El-Shafey, H. A., Ismail, A. M., Fahmy, Zeinab, M. and Zein El-Abeden, A. (1998) Pathogenic variation in Cephalosporium maydis. Phytopathology, 88 (9), S25. (Abst).

El-Fangary, I. M. (1975) Studies on the late wilt disease of maize. Further studies on the mechanism of resistance and susceptibility to the disease. $P h . D$. Thesis, Fac. Agric., Cairo Univ., Egypt.

El-Laithy, B. E. A. (1996) Studies on relationship between nitrogen fixers micro-organisms and root, and stalk rot fungi of maize. Ph. D. Thesis, Fac. Agric., Zagazig Univ., Egypt.

El-Shabrawy, A. M., Amien, A. M. and Bakheit, B. R. (1987) Effect of maize variety, method of infection, date of planting and plant phenols and sugar content on common smut disease. Assiut J. Agric. Sci., 18 (2), 5-17.

El-Shafey, H. A., and L. E. Claflin. (1999) Late Wilt. In: D. G. White, (ed.), Compendium of Corn Diseases (3rd). St. Paul: APS Press, pp. 43-44.

El-Shafey, H. A., Abd El-Rahim, M. F. and Reffaat, M. M. (1979) A new Cephalosporium-wilt disease of grain sorghum in Egypt. Third Egypt.Phytopathol., 514-532.

El-Shafey, H. A., Dawood, Nadia A., IBrahim, T. F., Ahmed, S. A. Z. and El-Bordfasy, M. A. (1985) Antagonism between soil micro flora and late wilt of maize fungs Cephalosporium maydis (Egypt). Agric. Res. J. Suez- Canal Univ., Ismailehah, Egypt, 3, 1194-1207.

El-Shafey, H. A., El-Shorbagy, F. A., Khalil, Ikbal, I. and ElAssiuty, E. M. (1988) Additional sources of resistance to late wilt disease of maize caused by Cephalosporium maydis. Agric. Res. Rev., 66 (2), 221-230.

Fadle, F. A. M. (1968) Studies on some factors affecting late wilt and black bundle disease of maize in U. A. R. Ph. D. Thesis, Fac. Agric. Ain Shams Univ., Cairo, Egypt.

Env. Biodiv. Soil Security Vol.1 (2017)
Fayzalla, E. A.; Sadik, E. A., El-Wakil, M. A. and Gomah, A. A. (1994) Soil solarization for controlling Cehhalosporium maydis. The causal of late wilt disease of maize in Egypt. Egypt. J. Phytopathol., 22 (2), 171-178.

Folin, D. and Denis, W. (1912) On phospho tungsticphosphomolybdic compounds as color reagents. $J$. Biol. Chem., 12, 239-243.(C. F. Gouda, M. I. M. M., 1996)

Gouda, M. I. M. (1996) Studies on maize leaf blight disease in Egypt. M. Sc. Thesis, Fac. Agric., Menufiya Univ., Egypt.

Hassaballa, E. A., El-Morshidy, M. A.; Khalifa, M. A., El-Hinnawy, H. H. and El-Naggar, G. R. (1987) Selection methods for yield and resistance to latewilt disease in maize. 1 . Performance of S1 lines. $J$. Agric. Sci., 18 (2), 146-161.

Jain, K. L., S. R. S. Dange, and K. L. Kothari. (1974) Stalk rots of maize in

Johan, Helen, and Dickson, D. A. (1945) A soluble substance in corn stalks that retards growth of Diplodia zea in culture. J. Agric. Res., 71 (3), 89111.

Khalifa, I. A. (2000) Comparative studies on some graminaceous plants infested by some diseases. M. Sc. Thesis, Fac. Agric., Al-Azhar Univ., Egypt.

Kostandi, Sofia, F. (1979) Study on the evaluation of some maize lines and populations. Evaluation of maize stocks resistance to late wilt disease (Cephalosporium maydis). M. Sc. Thesis, Fac. Agric., Alex. Univ., Egypt.

Mansour, I. M. S. K.(1962) Studies on stalk-rots of maize in U. A. R.: the slow-wilt disease. $M . S c$. Thises, Fac. Agric., Cairo Univ., Egypt.

Nazim, M., El-Assiuty, E. M., El-Shennawy, Z.,ElShanawani, M. Z. and Zein El-Abedeen, A. (1990) Source of variation in Cephalosporium maydis; the causal of late wilt of maize. $4^{\text {Th }}$. International Mycological.Congress. (Imc4). Regensburg, Germany, ( F. R. G.). $28^{\text {Th }}$ Augst- $3^{\text {rd }}$ September. (C.F.Awad, H.E. M. F., 2002)

Nicholson, R. L. (1992) Phenolic compounds and their role in disease resistance. Ann. Rev. Phytopathol., 30, 369-389 Rajasthan. Farm and Factory 8(10), 20-23.

Rushdi, M. H., Abd El-Razik, A. A. and Sadik, E. A. (1975) Studies on the nature of resistance in maize to Cephalosporiummaydis infection. Assiut $J$. 
Agric., Sci., 6 (3), 61-69.

Sabet, K. A., Zaher, Effat A. M., Samra, A. S. and Mansour, I. M. (1970) Pathogenic behaviour of Cephalosporium maydis and C. acremonium. Ann. Appl. Biol., 66, 257-263.

Sadik, E. A. (1973) Studies on Cephalosporiummaydis the incitant of late wilt of maize. M. Sc. Thesis, Fac. Agric., Assiut Univ., Egypt.

Saeed, F. A., Abou El-Seood M. S. and Darwish, Azziza, K. (1990) Anatomical structure of corn roots in relation to their resistanc to late wilt disease. Assiut J. Agric. Sci., 21 (5), 179-191.

Saleh, Mona, M. M. (2002) Biological control of some soil born disease on corn. M. Sc. Thesis, Fac. Agric., Kafr El-Sheikh, Tanta Univ., Egypt.

Samra, A. S., Sabet, K. A. and Abd El- Rahim, M. F. (1966) Effect of soil conditions and cultural practices on infection with stalk-rots. In investigations on stalk- rot disease of maize in U. A. R. Plant. Prot. Dept. Bull., Min. Agric., U. A. R., 117-164.

Samra, A. S., Sabet, K. A., Hingorani, M. K. (1963) Late wilt disease of maize caused by Cephalosporium maydis. Phytopathology, 53, 402-406.

Sass, J.E.(1961)Elements OfBotanical Microtechnique. McGraw-Hill Book Co., Inc., New York. (C.F.Abd El-Ghani, Haifa, S., 1987)

Satyanarayana, E. (1995) Genetic studies of late wilt and turcicum leaf blight resistance in maize. Madras., Agric. J.,82 (11), 608-609 (Abst).
Shetty, T. A. S., Kumar T. B. A., Gowda, K .T. P., Hattappa, S., Ramaswamy, G. R. and Prasad, Narayana (2001) Biochemical changes due to Peronosclerospora sorghi infection in resistant and susceptible maize genotypes. Environment and Ecology, 19 (4), 751-755.

Singh, S.D. and Siradhana, B-S. (1987) Influence of some environmental conditions on the development of late wilt of maize induced by acaephalosporium maydis. Indian J. Mycology and Plant. Pathol., 17 (1), 1-5.

Snell, F. D and Snell, C. T. (1953) Colorimetric Methods Of Analysis Including Some Turbidmetric And Mephalometric Methods. D.vanNortrand Company Inc. Tormato- New York, Londone, Vol. III Organic-1, pp 606.

Thomas, W. and Dutcher, R. A. (1924) Picric acid methods for carbohydrate. J. Amer. Chem. Soc., 46,1662-1669.

Yassin, M. A. (2000) Diversity in isolates of late wilt of maize in Egypt. M. Sc. Thesis, Fac. Agric., Cairo Univ., Egypt.

Zaher, Effat, A. M. (1974) Studies in the stalk-rot complex of maize: Survival of Cephalosporium acremonium in soil. Ph. D. Thesis, Fac. Agric., Cairo Univ., Egypt.

(Received $22 / 11 / 2017$; accepted $26 / 12$ /2017) 